Article

\title{
Implementing Open Innovation Using Quality Management Systems: The Role of Organizational Commitment and Customer Loyalty
}

\author{
Zoltán Krajcsák® \\ Department of Management, Budapest Business School, 1149 Budapest, Hungary; krajcsak.zoltan@uni-bge.hu \\ Received: 26 August 2019; Accepted: 28 October 2019; Published: 30 October 2019 \\ check for \\ updates
}

\begin{abstract}
Open innovation contributes to serving the customers of organizations with higher quality, as the customers become an active part of the innovation process. A successful solution for implementing open innovation can be achieved if organizations first create a total quality management (TQM) culture and then build on this foundation an ISO 9004:2018. The success of a quality management system depends first and foremost on the attitudes of the stakeholders, and the importance of technological and other conditions is only secondary. The goal in developing a successful philosophy of TQM is to build and sustain the leaderships' and employees' commitment, while the key to the success of ISO 9004:2018 is to establish and maintain the employees' commitment and customer loyalty. The case study presented in this article demonstrates the need to increase the affective and normative commitment of leaders and employees in TQM, and after its implementation, there is a need to increase the employees' continued commitment and customer loyalty in ISO 9004:2018 in order to succeed in quality management systems and open innovation.
\end{abstract}

Keywords: open innovation; TQM; ISO 9004:2018; organizational commitment; customer loyalty

\section{Introduction}

In classic closed organizational innovation, if the intention to improve the quality of the services is explicitly or implicitly reflected in the management's value system, the organization will seek to fully understand customer needs and requirements and incorporate processes for this purpose into its operating procedures. It is cheap and expedient, but at the same time it is considered a slow solution. By the time an organizational innovation is realized through internal development, consumer needs may change. Closed innovation is also referred to as vertical development, in which the products and services are the result of internal innovation [1].

In contrast, open innovation is characterized by the integration of external knowledge with the internal knowledge of the organization and to this end, a targeted innovation incentive scheme is used to ensure that external-internal cooperation is sustainable [2]. However, open innovation may also have disadvantages that are less addressed in the scientific literature, such as when sharing resources cheaply or for free, it is difficult to protect intellectual property when the results of the innovation need to be shared with others [3]. Open innovation is an obvious solution for organizations that want to respond to the challenges of globalization, rapid technological development, and the change of individuals' expectations of their careers.

In open innovation, users are involved from the very beginning of the innovation process. They become creators of new products and service designs [4]. The question is how this customer participation can be supported by organizational tools. Organizations that operate quality management systems are very successful in open innovation. Whether it is any quality management system, such an operating standard or a quality philosophy, its users are committed to continuous improvement of 
quality and to the satisfaction of customer demands [5,6]. However, it is not clear which quality management system is more conducive to open innovation: one that, driven by leadership, creates a quality culture and understanding of the importance of a quality philosophy to its employees; or one that specifies the quality development steps and the methods involved as a standard. In our approach, the integration of the two concepts of quality provides an effective solution: first there is a need for cultural and attitudinal change and then, building on this change, it makes sense to introduce quality standards when employees are not only enforcing, but also believing in them. An example of the latter is the ISO 9000 standard system, which is able to support the organizational innovation of supply chains [7].

An example of such an application is the combination of total quality management (TQM) and the ISO 9004:2018 system. The introduction and the maintenance of quality management systems often fail due to the lack of commitment or insufficient consideration of the customer needs [8]. Thus, in a quality-oriented approach to open innovation based on partnerships, the employees' commitment and customer loyalty seem to play key roles. However, neither quality philosophies nor standards provide clear suggestions about how these can be enhanced. The model presented in this article attempts to do this.

\section{Supporting Open Innovation through Quality Management Systems}

One of the biggest challenges, not only for large companies, but also for small and medium-sized enterprises, in implementing open innovation is how to continuously measure the customer needs with their own resources in a cost-effective way [9]. Other studies emphasize not only the need to involve the external stakeholders and to encourage the customers in these processes, but also the motivation of their own employees, since the innovation process requires a combination of internal and external knowledge [10]. The close relationship with the customers and the constant work with them have been emphasized by others as a success of open innovation, not only in production, but also in services [11]. Such close and long-term co-operation requires significant resources from organizations, but especially a dedicated policy and culture. Organizations that have already learned and successfully put into practice the potential for cooperation, quality development, common thinking, integration, and knowledge sharing are in a better position to move towards open innovation. These are values that can be found in larger quality management systems, whether it is a quality philosophy or an operating standard.

\subsection{Total Quality Management for Open Innovation}

There are many definitions of TQM, and these generally differ in which management functions are included among the principles [12]. What they all have in common is that they all approach the concept as a management philosophy in which the leaders' commitment to quality, communication to the employees and external stakeholders, customer focus, continuous improvement, evidence-based decision-making, process management-based planning, and the involvement of employees are equally important. Both TQM application and innovation enhance the organizational performance, and there is a direct positive relationship between TQM and innovation [13]. Thus, in a strong TQM-based organization, innovation can be more easily managed. Quality systems with other TQM bases also bring to the forefront innovation and development (e.g., Six Sigma, Lean management). A common feature of these practices, however, is that user organizations tend to spend too much energy on the technological implementation and too little on the organizational culture and the human factor [14].

Lorente et al. [15] also argue that TQM does not impede innovation within the organization, but rather in some dimensions promotes it. TQM and reengineering combined have been found to provide aggregated results in the organizational improvements made. Given that in TQM it is important to improve both the internal processes and the external relationships, the question arises: If an organization wants to create open innovation practice, then how can TQM help in this? Out of the seven principles of TQM, four deal with quality improvement, specifically in relationships outside 
the organization (customer focus, relationship with suppliers, competitors, communication) [16], but other dimensions that focus on the internal processes, such as top management leadership, employee relations, and process management, indirectly also affect the relationships with customers and consumers. Customer focus, and relationships with suppliers and competitors focus not only on increasing customer satisfaction and reducing the time spent on finding business partners, but the customers also may become loyal in the long-term by them. This loyalty and satisfaction together make it easier for stakeholders to become involved in organizational development. Based on the above, we are looking for the answer for the following research question:

RQ1A. Does TQM support implementing a culture of open innovation?

\subsection{ISO 9004:2018 for Open Innovation}

While TQM primarily focuses on the culture of leadership, there are standards that similarly strive to achieve business excellence, but these set specific benchmarks, verifiable steps, and criteria to achieve this. An example of such standards is ISO 9004, an updated version of which was published in 2018 after 2009 [17]. Both are based on the ISO 9000 standard of the year of 2005 and 2015, which contains the principles of the standards included in the system. Since ISO 9001:2008 does not regularize involvement and motivation [18], which are particularly important values for implementing open innovation, ISO 9001 focuses primarily on measuring efficiency, while ISO 9004 focuses on improving the efficiency [19], we are dealing with ISO 9004. While ISO 9001 is suitable for quality assurance of customer-specific products, ISO 9004 beyond that can be used to continuously improve performance to gradually achieve excellence [20].

The structural differences between the principles of ISO 9000:2005 and ISO 9000:2015 are illustrated in Table 1 [21,22]. It can be seen that the number of principles in the revised standard of ISO 9000 was reduced from eight to seven. Not only participation and involvement is important in the new approach, which are replaced by the commitment. Commitment expresses that employee participation is not only for the consequences that are offered by management, but usually comes from an inner conviction, becoming a self-sustaining attitude. Additionally, mutually beneficial supplier relationships are replaced by relationship management, which expresses the importance of customers as they are taken to the same level with suppliers and other partners. Finally, a significant change is that development and innovation are not necessarily continuous activities; a leap in innovation is more viable in practice. In open innovation, if we rely on customer feedback, we need to treat them as strategic partners. The volunteering-based quality development is also reflected in other approaches (e.g., Lean Six Sigma), and the appreciation of commitment can also support open innovation.

Table 1. Quality management principles of ISO 9000:2005 according to [21] and the main elements of ISO 9000:2015 according to [22].

\begin{tabular}{ccc}
\hline $\begin{array}{c}\text { Management Principles in ISO } \\
\mathbf{9 0 0 0 : 2 0 0 5}\end{array}$ & $\begin{array}{c}\text { Management Principles in ISO } \\
\mathbf{9 0 0 0 : 2 0 1 5}\end{array}$ & A Brief Evaluation of the Change \\
\hline Customer-focus & Customer-focus & - \\
\hline Leadership & Leadership & - \\
\hline $\begin{array}{c}\text { Involvement of people } \\
\text { Mutually-beneficial supplier } \\
\text { relationships }\end{array}$ & Eelationship management & $\begin{array}{c}\text { The customers become as strategic partners } \\
\text { as the others }\end{array}$ \\
\hline Process approach & Process approach & - \\
\hline $\begin{array}{c}\text { System approach to management involvement is transformed } \\
\text { Entinual improvement }\end{array}$ & - & $\begin{array}{c}\text { The bureaucratic form of the management } \\
\text { is reduced and the hierarchy is destroyed }\end{array}$ \\
\hline $\begin{array}{c}\text { Factual approach to decision } \\
\text { making }\end{array}$ & Evidence-based decision making & $\begin{array}{c}\text { Development and innovation can be leaps } \\
\text { and bounds. }\end{array}$ \\
\hline
\end{tabular}


Accordingly, the structure of ISO 9004 has been changed, the content of which is shown in Table $2[17,23]$. While ISO 9004:2005 often served as a supplement to ISO 9001, ISO 9004:2018 no longer derives the regulatory requirements from the structure of ISO 9001.

Table 2. Essential elements of the structure of ISO 9004:2009 [23] and ISO 9004:2018 [17].

\begin{tabular}{ccc}
\hline $\begin{array}{c}\text { Essential Elements of ISO } \\
\text { 9004:2009 }\end{array}$ & $\begin{array}{c}\text { Essential Elements of ISO } \\
\mathbf{9 0 0 4 : 2 0 1 8}\end{array}$ & A Brief Evaluation of the Change \\
\hline $\begin{array}{c}\text { Managing for the sustained } \\
\text { success of an organization }\end{array}$ & $\begin{array}{c}\text { Identity of an organization } \\
\text { (mission, vision, values, culture) }\end{array}$ & $\begin{array}{c}\text { There are no lasting successes without } \\
\text { consciously shaping the organizational } \\
\text { culture }\end{array}$ \\
\hline Strategy and policy & $\begin{array}{c}\text { Leadership (strategy, policy, } \\
\text { objectives) }\end{array}$ & $\begin{array}{c}\text { Leadership principles and practices become } \\
\text { goal-oriented }\end{array}$ \\
\hline Resource management & Resource management & - \\
\hline $\begin{array}{c}\text { Process management } \\
\text { analysis, and review }\end{array}$ & Process management & $\begin{array}{c}\text { The role of the benchmarking in planning, } \\
\text { and the analysis of the weaknesses and } \\
\text { risks in the management system become } \\
\text { more valuable }\end{array}$ \\
\hline $\begin{array}{c}\text { Improvement, innovation, and } \\
\text { learning }\end{array}$ & $\begin{array}{c}\text { Performance analysis and } \\
\text { evaluation }\end{array}$ & - \\
\hline
\end{tabular}

Based on its structural elements, ISO 9004:2018 has a stronger external orientation than its earlier version, as managers' activity is not only determined by strategy and policy, but also derives that proactively from the goals. It is important to realize that lasting success can only be achieved by managing the elements of the internal organizational culture in a planned way at first, as this is the basis of the processes and activities. Similarly, the fact that benchmarking in the 2018 version is much more detailed, which requires mutual cooperation with external partners, also suggests compatibility with open innovation. Based on the above, we are looking for answers to the following research questions:

RQ1B. Does ISO 9004:2018 support the implementing of an open innovation culture?

RQ1C. Based on RQ1A and RQ1B, can TQM and ISO 9004:2018 be used simultaneously for open innovation, and if so, in what order should these be implemented?

\section{Leaders' and Employees' Commitment in the TQM}

The success of TQM implementation depends on the commitment of management, and on the commitment and efficiency of the employees [24]. TQM is also interpreted as a corporate governance culture, but it means much more. It is not only related to management, as it makes every employee interested in quality improvement, which is confirmed by the fact that employee job satisfaction is also higher in TQM organizations [25]. Constant collaboration in open innovation, integration of development ideas, and the intent to continually identify needs can only be present if every member of the organization is committed to the goals of TQM. This commitment empowers employees to understand the organizational missions and continually seek new solutions to reach ever higher standards [26]. The commitment of the internal stakeholders of the organization is important at two levels. On the one hand, the surveys show that the main reason for TQM failure or impediment is the lack of effort on the part of the employees [27]. The solution to this is to use successful solutions to enhance employees' commitment as a central element of TQM. In practice, the problem is often that attempts are made to enhance this commitment but not by the proper motivational methods. On the other hand, many executives involved in the introduction of TQM experience the challenges and the initial failures of TQM and believe that it is not an effective way to improve quality [27]. The solution to this is also in commitment. A manager who is both committed to his or her profession and organization puts more effort into its goals, so managers with a high level of commitment can be 
more successful in implementing TQM. Finally, an important consequence is that otherwise committed managers can find more effective solutions to motivate their employees.

The three main dimensions of organizational commitment are affective, normative, and continuance commitment [28]. Although not all research supports the uniqueness of these three dimensions [29-31], so far, most scientific research is based on this model. Continuance commitment expresses a calculative intention of staying in which the employee remains a member of the organization for as long as it is worthwhile for him or her. It is based on Becker's side-bet theory, according to which a worker stays in the organization until he or she finds a better alternative by evaluating the negotiated and acquired goods, such as the salary, the relationships he or she has built up, and his or her efforts so far [32]. Affective commitment expresses an employee's emotional attachment to his or her organization or staff. This dimension is considered to be the strongest and the most genuine commitment, as it has the strongest correlation with the variables we are expecting from it, e.g., performance, job satisfaction, intention to stay in the organization, etc. [33-35]. The normative commitment has moral foundations. In this attitude, the employee feels that he or she owes it the organization to maintain his/her membership in it, as although there is not any external compulsion in the decision, he or she nevertheless feels pressured, and internally inclined to reciprocate all that was received. The correlation of normative commitment with individual performance and with absence is practically negligible compared to affective commitment $[29,31]$. Therefore, some research suggests that employee commitment is still a one-dimensional variable where only the affective commitment can be interpreted [29]. This approach is simplistic as it ignores the indirect effects of the normative (and continuance) commitment on the organizational performance and organizational culture. Given that the continuance commitment is an "if-then" attitude, we will no longer consider it in TQM, where explicit belief in values supports quality development, not prescriptions, criteria, and its accountable rewards.

Normative commitment is not related to job satisfaction [36]. Among TQM practices, teamwork and organizational culture have a positive relationship with job satisfaction, but are not affected by customer focus, education, and training, and the leadership and top management commitment [37]. However, a successful TQM introduction may require that the professionalism and normative commitment of the leaders and employees facilitate the continuous participation in the organizational training programs and help employees to pick up the customer focus. One dimension of leadership is ethical dimension, where the main source of influence is morality [38].

It is the responsibility of managers to create an organizational culture that supports TQM with the employees as true team members to motivate them for the training programs and volunteering, and to make the employees see customer satisfaction as an intrinsic value that deserves extra performance. Implementing TQM principles, therefore, requires employees to have affective commitment (organizational culture and teamwork) and normative commitment (education and training, leadership and top management commitment, and customer focus) at the same time, and the managers must have a high level of normative commitment.

RQ2. What type(s) of commitment must managers and employees have to implement TQM successfully?

\section{Employee Commitment and Customer Loyalty in the ISO 9004:2018}

If TQM is implemented first to deliver quality development and open innovation, and make a quality oriented culture in the organization with committed employees, then this can be a basis for building new solutions in the next step to achieve sustainable successes with measurable criteria, metrics, and requirements for all members of the organization. This new system to be introduced should be consistent with TQM in terms of purpose and design. Although TQM also has an external orientation [37], the internal and external focuses are approximately balanced in ISO 9004:2018 [17]. While TQM focuses on developing the organizational culture, ISO 9004:2018 addresses the system as a whole, taking into account all external and internal resources. Customer focus appears in both, but ISO 9004 contains detailed instructions on how to development it. The relationships between the elements of TQM practices and the elements of ISO 9004:2018 are shown in Table 3. 
Table 3. Relationships and differences between total quality management (TQM) [37] and ISO 9004:2018

[17], depending on the required types of commitment in each dimension.

\begin{tabular}{|c|c|c|}
\hline TQM Practices & $\begin{array}{c}\text { Essential Elements of ISO } \\
\text { 9004:2018 }\end{array}$ & $\begin{array}{c}\text { The Necessary Dimension(s) of } \\
\text { Commitment }\end{array}$ \\
\hline Organizational Culture & $\begin{array}{c}\text { Identity of an Organization } \\
\text { (Mission, Vision, Values, Culture) }\end{array}$ & Affective Commitment (TQM) \\
\hline $\begin{array}{l}\text { Leadership and Top Management } \\
\text { Commitment }\end{array}$ & $\begin{array}{c}\text { Leadership (Strategy, Policy, } \\
\text { Objectives) }\end{array}$ & Normative Commitment (TQM) \\
\hline \multirow{3}{*}{ Teamwork + Customer Focus } & Resource Management & \multirow{3}{*}{$\begin{array}{c}\text { Affective Commitment (TQM) } \\
\text { +Normative Commitment (TQM) } \\
\text { +Continuance Commitment (ISO 9004:2018) } \\
\text { +Customer Loyalty } \\
\text { (ISO 9004:2018) }\end{array}$} \\
\hline & Process Management & \\
\hline & $\begin{array}{c}\text { Performance Analysis and } \\
\text { Evaluation }\end{array}$ & \\
\hline Education and Training & $\begin{array}{l}\text { Improvement, Learning, and } \\
\text { Innovation }\end{array}$ & Normative Commitment (TQM) \\
\hline
\end{tabular}

The TQM practices have five essential elements and ISO 9004:2018 has six essential elements. Some of the TQM elements clearly correspond to some elements of ISO 9004. An example is Organizational Culture, which is equivalent in its content to the element of Identity of an Organization in ISO 9004. Creating a unified organizational culture requires emotional commitment in order for everyone to truly want the change, to agree with, and to actively pursue their goals. Affective commitment also facilitates the development of intergroup and intra-group dynamics.

In TQM, the Leadership and Top Management Commitment element can be mapped to the Leadership (Strategy, Policy, Objectives) element in ISO 9004:2018, and in TQM, the Education and Training element is similar to the internal focus of the Improvement, Learning, and Innovation element in ISO 9004:2018. Both item pairs are supported by the normative commitment, as described above.

In TQM, Teamwork and Customer Focus together cover the meaning and requirements of Resource Management, Process Management, and Performance Analysis and Evaluation elements in ISO 9004:2018. The ability and willingness to work in a team is required for an organization to operate according to the process management requirements [39]. This expectation can be supported by a clearly communicated and fairly designed performance evaluation system [40]. These three elements of the ISO 9004:2018 (Resource Management, Process Management, and Performance Analysis and Evaluation) can be achieved by affective commitment in the dimensions of Teamwork, by normative and continuance commitment in the dimensions of Customer Focus and Performance Analysis and Evaluation, and ultimately, by increasing the customer loyalty in all three dimensions.

RQ3. What types of commitment are required from the employees and the customers to implement the ISO 9004:2018 successfully?

\section{Case Study}

The following example is intended to illustrate the above theoretical approaches in a practical case. Due to the sensitivity of the topic, this organizational example is presented anonymously. The case chosen is, of course, arbitrary and does not prove the generalizability of the theoretical relationships presented above, but the specific example supports them.

The profile of the $\mathrm{ABC}$ Company is primarily in software manufacturing, but it also has significant $R \& D$ activities and has developed dozens of IT patents in the last decade. The Company has a dominant role in the IT sector and holds over 10 percent of the market share at the national level in its core business. In the business year preceding the introduction of quality management systems, the Company had 312 full-time employees. Following the replacement of the director of corporate strategy, many senior management positions were replaced. The strategic manager reviewed the business situation and operational features of the Company and concluded that:

- quality management could significantly improve the organizational performance; 
- corporate R\&D activity has declined over the last three years and IT support services have begun to replace it, and this has not been in line with the strategic ideas.

To this end, a decision was made to introduce TQM. TQM was expected to improve the quality of the employees' jobs, for work to be more demanding, for employees to seek professional challenges more often, and for employees to have a closer connection with the customers through the R\&D activities in the open innovation that was developed by the TQM culture. To this end, the management trained the employees to learn the values of TQM, executives underwent special quality training, and executives made major changes at departmental and team levels to enhance the employees' commitment and loyalty.

Initially, the introduction of TQM was difficult due to a lack of commitment of mid-level managers to quality improvement. Those who had been working for the company for a significantly longer period were more successful in implementing TQM. These senior leaders were able to identify with the strategic expectations as the junior managers left the company in large numbers. Certainly, the managers knew that the success of the change mainly depended on the employees, so they also tried to increase their motivation and satisfaction in line with the expectations of TQM. They offered non-monetary rewards and consequences in exchange for their expected behavior, which enabled them to improve the quality of the emotional relationship between the workplace and the employees.

All these slow, initially seemingly successful changes were not enough, but the organizational culture was developed in line with TQM. The two most important results of the leaders were that:

- they achieved a higher level of job atmosphere and satisfaction among the employees and a significant reduction in absenteeism;

- employees' own efforts to train and develop themselves became a real value in the organization, which was also supported by organizational tools.

However, many people perceived the lack of measurable criteria in line with the changes as a TQM failure (e.g., Who is a real motivated employee? How many organizational training programs accomplished in a year is excellent? How should the success of the customer focus be measured?), and did not help the open innovation. Although joint development work with the customers became more efficient, development was still operating within the Company and the external knowledge had not been effectively integrated into the innovation process.

Therefore, in the third year after the introduction of TQM, the senior management decided to implement the standard of ISO 9004:2009 and later the ISO 9004:2018. It was believed that quality orientation was generalized with the TQM philosophy and was a good basis for applying ISO 9004, which is based on standards and accountability.

Along with the introduction of ISO 9004:2018, the potential for open innovation based on organizational self-evaluation was increased significantly because:

- in terms of Resource Management, customers were considered as important a resource as were the employees, as required by the standard;

- $\quad$ according to the Process Management requirements, the organizational process management already not only coordinated and streamlined the internal organizational processes, but also was able to organize these with relevant external processes on the customer and supplier side;

- in line with the requirements of Performance Analysis and Evaluation, they developed an incentive system that aimed to increase customer loyalty, which is an essential element for open innovation, and rewarded employees with both premiums and opportunities to advance.

Only a few months have passed since the introduction of the ISO 9004:2018, and this is not enough time for a sound assessment. However, the initial results show that the introduction of ISO 9004 for the open innovation was a good complement to TQM. 


\section{Discussion}

Figure 1 illustrates the conclusions of the theoretical considerations and the case study.

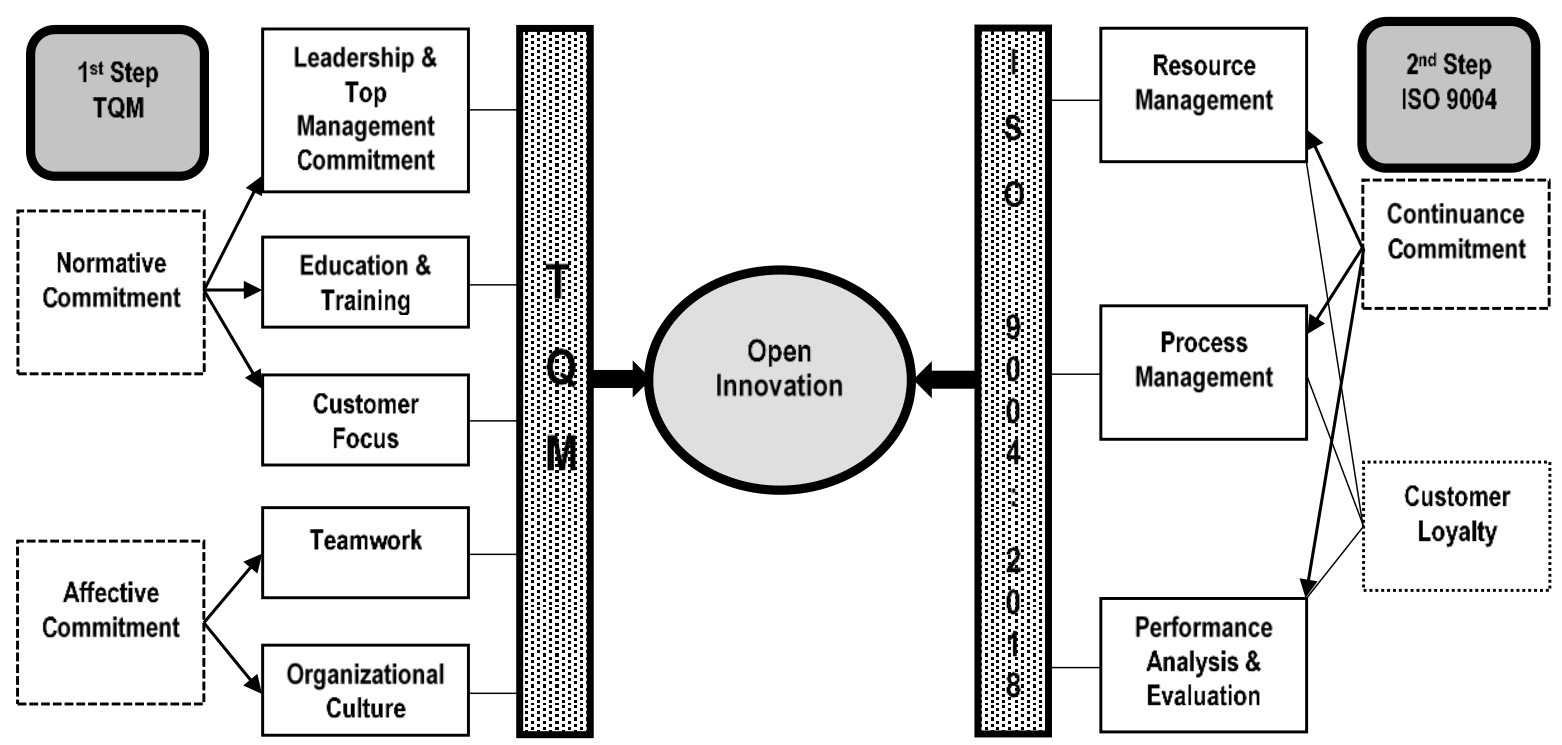

Figure 1. Open innovation supported by TQM (1) and ISO 9004:2018 (2).

A successful implementation of open innovation can be achieved by implementing TQM first (Step 1), and then building on a quality assurance system such as ISO 9004:2018 (Step 2). The figure includes only those elements of ISO 9004:2018 that are not redundant with TQM, and none of the commitment dimensions that support the ISO 9004:2018 have any redundancy with TQM (the affective and normative commitment).

The results are as follows:

- Applying quality management systems helps to create open innovation by enabling organizations to make the customers (and other external stakeholders) be real collaborators through cultural change and quality management.

- An effective-but not exclusive-solution to open innovation is to implement TQM first, and then, once its values have been consolidated, to implement the ISO 9004:2018.

- Most quality management systems rely heavily on employees' commitment. TQM can support open innovation by targeted enhancement of affective and normative commitment, and the ISO 9004:2018 can also support open innovation by targeted enhancement of continuance commitment and customer loyalty.

- There are interdependences between customer loyalty and process management; resource management; and the performance analysis and evolution, meaning that these elements of the ISO 9004:2018 individually strengthen the customer focus, and stronger customer focus helps to develop these functional areas.

The results show that the introducing the TQM and the ISO 9004:2018 standards one after the other, and operating both, may effectively support open innovation. All types of employee commitment are needed to achieve this, but these commitment dimensions need to be targeted by management. In the future, it is also advisable to investigate the relevance of the results by quantitative methods.

Funding: The APC was funded by Budapest Business School.

Conflicts of Interest: The author declares no conflict of interest. 


\section{References}

1. Chesbrough, H. Open Innovation: Where We've Been and We're Going. Res. Technol. Manag. 2012, 55, $20-27$. [CrossRef]

2. Salge, T.O.; Bohné, T.M.; Farchi, T.; Piening, E.P. Harnessing the value of open innovation: The moderating role of innovation management. Int. J. Innov. Manag. 2012, 16, 1-26. [CrossRef]

3. Dahlander, L.; Gann, D.M. How open is innovation? Res. Policy 2010, 39, 699-709. [CrossRef]

4. Gassmann, O.; Enkel, E.; Chesbrough, H. The future of open innovation. R D Manag. 2010, 40, $213-221$. [CrossRef]

5. Yusr, M.M. Innovation capability and its role in enhancing the relationship between TQM practices and innovation performance. J. Open Innov. Technol. Mark. Complex. 2016, 2, 1-15. [CrossRef]

6. Hernandez-Vivanco, A.; Bernardo, M.; Cruz-Cázares, C. Relating open innovation, innovation and management systems integration. Ind. Manag. Data Syst. 2016, 116, 1540-1556. [CrossRef]

7. Shi, Y.; Lin, W.; Chen, P.-K.; Su, C.-H. How can the ISO 9000 QMS improve the organizational innovation of supply chains? Int. J. Innov. Sci. 2019, 11, 278-298. [CrossRef]

8. Seetharaman, A.; Sreenivasan, J.; Boon, L.P. Critical Success Factors of Total Quality Management. Qual. Quant. 2006, 40, 675-695. [CrossRef]

9. van de Vrande, V.; de Jong, J.P.J.; Vanhaverbeke, W.; de Rochemont, M. Open innovation in SMEs: Trends, motives and management challenges. Technovation 2009, 29, 423-437. [CrossRef]

10. West, J.; Gallagher, S. Challenges of open innovation: The paradox of firm investment in open-source software. $R$ D Manag. 2006, 36, 319-331. [CrossRef]

11. Chesbrough, H. Bringing Open Innovation to Services. MIT Sloan Manag. Rev. 2011, 52, 84-91.

12. Hellsten, U.; Klefsjö, B. TQM as a management system consisting of values, techniques and tools. TQM Mag. 2000, 12, 238-244. [CrossRef]

13. Maistry, K.; Hurreeram, D.K.; Ramessur, V. Total quality management and innovation: Relationships and effects on performance of agricultural R\&D organisations. Int. J. Qual. Reliab. Manag. 2017, 34, 418-437.

14. Dahlgaard, J.J.; Dahlgaard-Park, S.M. Lean production, six sigma quality, TQM and company culture. TQM Mag. 2006, 18, 263-281. [CrossRef]

15. Lorente, A.M.R.; Dewhurst, F.; Dale, B.G. TQM and business innovation. Eur. J. Innov. Manag. 1999, 2, 12-19. [CrossRef]

16. Singh, P.J.; Smith, A.J.R. Relationship between TQM and innovation: An empirical study. J. Manuf. Technol. M. 2004, 15, 394-401. [CrossRef]

17. ISO-International Organization for Standardization. ISO 9004: 2018. Guidance to Achieve Sustained Success. 2018. Available online: https://www.iso.org/standard/70397.html (accessed on 19 August 2019).

18. Boys, K.A.; Wilcock, A.E. Improving integration of human resources into quality management system standards. Int. J. Qual. Reliab. Manag. 2014, 31, 738-750. [CrossRef]

19. Arunachalam, T.; Palachinamy, Y. Does the soft aspects of TQM influence job satisfaction and commitment? An empirical analysis. TQM J. 2017, 29, 385-402. [CrossRef]

20. Boys, K.; Karapetrovic, S.; Wilcock, A. Is ISO 9004 a path to business excellence? Opinion of Canadian standards experts. Int. J. Qual. Reliab. Manag. 2004, 21, 841-860. [CrossRef]

21. ISO-International Organization for Standardization. ISO 9000: 2005. Fundamentals and Vocabulary. 2005. Available online: https://www.iso.org/standard/42180.html (accessed on 19 August 2019).

22. ISO-International Organization for Standardization. ISO 9000: 2015. Fundamentals and Vocabulary. 2015. Available online: https://www.iso.org/standard/45481.html (accessed on 19 August 2019).

23. ISO-International Organization for Standardization. ISO 9004: 2009. Managing for the Sustained Success of an Organization-A Quality Management Approach. 2009. Available online: https://www.iso.org/standard/ 41014.html (accessed on 19 August 2019).

24. Amin, M.; Aldakhil, A.M.; Wu, C.; Rezaei, S.; Cobanoglu, C. The structural relationship between TQM, employee satisfaction and hotel performance. Int. J. Contemp. Hosp. Manag. 2017, 29, 1256-1278. [CrossRef]

25. Prajogo, D.I.; Cooper, B. The individual and organizational level effects of TQM practices on job satisfaction. Int. J. Manpower 2017, 38, 215-225. [CrossRef]

26. Harari, O. Three very difficult steps to total quality. Manag. Rev. 1993, 82, 39-42. 
27. Longenecker, C.O.; Scazzero, J.A. The ongoing challenge of total quality management. TQM Mag. 1996, 8, 55-60. [CrossRef]

28. Allen, N.J.; Meyer, J.P. The measurement and antecedents of affective, continuance, and normative commitment to the organization. J. Occup. Psychol. 1990, 63, 1-18. [CrossRef]

29. Mercurio, Z.A. Affective Commitment as a Core Essence of Organizational Commitment: An Integrative Literature Review. Hum. Resour. Dev. Rev. 2015, 14, 389-414. [CrossRef]

30. Hackett, R.D.; Bycio, P.; Hausdorf, P.A. Further Assessments of Meyer and Allen's (1991) Three-Component Model of Organizational Commitment. J. Appl. Psychol. 1994, 79, 15-23. [CrossRef]

31. Solinger, O.N.; van Olffen, W.; Roe, R.A. Beyond the Three-Component Model of Organizational Commitment. J. Appl. Psychol. 2008, 93, 70-83. [CrossRef]

32. Wasti, S.A. Commitment profiles: Combinations of organizational commitment forms and job outcomes. J. Vocat. Behav. 2005, 67, 290-308. [CrossRef]

33. Vandenberghe, C.; Bentein, K.; Stinglhamber, F. Affective commitment to the organization, supervisor, and work group: Antecedents and outcomes. J. Vocat. Behav. 2004, 64, 47-71. [CrossRef]

34. Carmeli, A. Perceived External Prestige, Affective Commitment, and Citizenship Behaviors. Organ. Stud. 2005, 26, 443-464. [CrossRef]

35. Meyer, J.P.; Paunonen, S.V.; Gellatly, I.R.; Goffin, R.D.; Jackson, D.N. Organizational Commitment and Job Performance: It's the Nature of the Commitment That Counts. J. Appl. Psychol. 1989, 74, 152-156. [CrossRef]

36. Suliman, A.; Iles, P. Is continuance commitment beneficial to organizations? Commitment-performance relationship: A new look. J. Man. Psychol. 2000, 15, 407-422. [CrossRef]

37. Ooi, K.-B.; Arumugam, V.; Teh, P.-L.; Chong, A.Y.-L. TQM practices and its association with production workers. Ind. Manag. Data Syst. 2008, 108, 909-927. [CrossRef]

38. González, T.F.; Guillén, M. Leadership ethical dimension: A requirement in TQM implementation. TQM Mag. 2002, 14, 150-164. [CrossRef]

39. Telleria, K.M.; Little, D.; MacBryde, J. Managing processes through teamwork. Bus. Proc. Man. J. 2002, 8, 338-350. [CrossRef]

40. Awasthi, V.N.; Chow, C.W.; Wu, A. Cross-cultural differences in the behavioral consequences of imposing performance evaluation and reward systems: An experimental investigation. Int. J. Account. 2001, 36, $291-309$. [CrossRef]

(C) 2019 by the author. Licensee MDPI, Basel, Switzerland. This article is an open access article distributed under the terms and conditions of the Creative Commons Attribution (CC BY) license (http://creativecommons.org/licenses/by/4.0/). 